\title{
Origin and route of establishment of the invasive Pacific oyster Crassostrea gigas in Scandinavia
}

\author{
Ellika Faust ${ }^{1, *}$, Carl André ${ }^{1}$, Sara Meurling ${ }^{2}$, Judith Kochmann ${ }^{3}$, Henrik Christiansen ${ }^{1,4}$, \\ Lasse Fast Jensen $^{5}$, Grégory Charrier ${ }^{6}$, Ane T. Laugen ${ }^{7,8}$, Åsa Strand ${ }^{1}$ \\ ${ }^{1}$ Department of Marine Sciences - Tjärnö, University of Gothenburg, 45296 Strömstad, Sweden \\ ${ }^{2}$ Department of Ecology and Genetics, Uppsala University, 75236 Uppsala, Sweden \\ ${ }^{3}$ Senckenberg Gesellschaft für Naturforschung, Senckenberg Biodiversität und Klima Forschungszentrum (SBiK-F), \\ 60325 Frankfurt am Main, Germany \\ ${ }^{4}$ Laboratory of Biodiversity and Evolutionary Genomics, KU Leuven, 3000 Leuven, Belgium \\ ${ }^{5}$ Fisheries and Maritime Museum, 6710 Esbjerg V, Denmark \\ ${ }^{6}$ Université de Bretagne Occidentale, Laboratoire des Sciences de l'Environnement Marin (LEMAR, UMR 6539, \\ UBO/CNRS/IRD/Ifremer), Institut Universitaire Européen de la Mer (IUEM), 29280 Plouzané, France \\ ${ }^{7}$ Novia University of Applied Sciences, 10600 Ekenäs, Finland \\ ${ }^{8}$ Department of Ecology, Swedish University of Agricultural Sciences, 75007 Uppsala, Sweden
}

\begin{abstract}
Identifying the routes and rates of introductions is fundamental for the understanding of marine invasions. Recurring introductions over the last 50 yr have led to the establishment of feral Pacific oyster Crassostrea gigas populations throughout Europe. In the northern countries, Sweden and Norway, the species first occurred in large numbers in 2006. Here, we investigated the relative importance of introduction via re-laying of cultured oysters imported for consumption from France, Ireland or the Netherlands, and dispersal of oyster larvae by ocean currents from wild oyster populations in Denmark. Using microsatellite DNA markers, we estimated genetic differentiation among Pacific oysters collected at 4 Swedish locations, 3 Norwegian locations and 9 potential source locations in Denmark, Ireland, the Netherlands and France. All Swedish samples and 1 Norwegian sample (Tromlingene) were genetically similar to each other and the Danish samples and showed significant genetic differentiation from all other populations. Consequently, it appears that the Pacific oyster populations in Sweden, Denmark and Tromlingene are closely connected and/or share a recent origin. The 2 remaining Norwegian samples (Hui and Espevik) differed from each other and all other populations, but showed similarities to wild oyster samples from Scandinavia and Ireland, respectively. Overall, the results underline a complex origin of Norwegian oysters, with gene flow from Swedish/Danish populations, as well as other unidentified sources. The apparent connectivity among most of the Scandinavian populations has implications for regional management of this invasive species, and highlights possible scenarios for other marine invasive species with a similar life history.
\end{abstract}

KEY WORDS: Population genetics - Microsatellites - Range expansion - Non-native species · Aquaculture $\cdot$ Connectivity $\cdot$ Scandinavia $\cdot$ Skagerrak

\section{INTRODUCTION}

Marine invasive species are a major threat to biodiversity (Costello et al. 2010) and can have substantial ecological and economic impacts. Introduction of nonnative species is often mediated by human activities,

${ }^{*}$ Corresponding author: ellika.faust@gmail.com such as shipping, trading and aquaculture. Once introduced, a successful invader can spread in the wild and establish feral populations, potentially leading to displacement of native species, changes in community structure and food webs, alterations in the abiotic environment, as well as function as a vector for parasites

(C) The authors 2017. Open Access under Creative Commons by Attribution Licence. Use, distribution and reproduction are unrestricted. Authors and original publication must be credited. 
and diseases (Crooks 2002). Genetic tools are particularly useful to analyse population structure and to investigate biological invasions, e.g. to determine dispersal mechanisms and the origin of non-native species (e.g. Balloux \& Lugon-Moulin 2002, Dlugosch \& Parker 2008, Geller etal.2010). Knowing the source population is not only vital to develop suitable management strategies for the species in question, but also helps to identify routes and vectors of introduction, which is crucial for predicting and hindering future invasions. At the same time, colonization histories of invasive species can be used to study processes determining genetic diversity of organisms in the marine realm.

One good example of this is the Pacific oyster, Crassostrea gigas (Thunberg 1793), which originates from the coastal waters of Japan and south-east Asia. It has been introduced to all continents except Antarctica for aquaculture purposes (Padilla 2010), and is now one of the most widely introduced marine invertebrates (Ruesink et al. 2005, Sousa et al. 2009). Despite the common belief that water temperatures in north-western Europe were too low to allow local reproduction (Drinkwaard 1998, Miossec et al. 2009), feral populations can now be found all over Europe, including Scandinavia (Wrange et al. 2010, Laugen et al. 2015) and the British Isles (Ruesink et al. 2005, Kochmann et al. 2012).

Different genetic markers have previously been applied to disentangle the Pacific oysters' complex population structure in Europe (Moehler et al. 2011, Kochmann et al. 2012, Rohfritsch et al. 2013, Lallias et al. 2015). Most of the studies identified a southern population group (stretching from Spain to south Wales) and a northern population group (from Ireland and north Germany to Sweden). Rohfritsch et al. (2013) identified a northern group of Pacific oyster collected from 2 Swedish and 2 Danish locations, suggesting natural introduction of the species in Sweden by larval dispersal with oceanic currents from Danish locations. However, their analyses also showed contrasting patterns of genetic structure within this northern group, since Swedish oysters were significantly differentiated from those in Limfjord in Denmark, but not from those in the Danish Wadden Sea.

The complex population structure in Scandinavian waters could be a result of several different factors, such as oyster population demographics, seed transfer for aquaculture production, re-laying of oysters and/or larval dispersal. The first introduction of the species to Scandinavian waters occurred at the beginning of the 1970s. From the early 1970s to the late 1990s, several million seed oysters were imported from around Europe to various locations along the
Danish coast for aquaculture experiments (Troost 2010). Commercial production was initiated in 1986 and ceased in 1998 (Wrange et al. 2010). In Norway, Pacific oysters were imported from the British Isles to a hatchery in Espevik on the Norwegian west coast in 1979 (Strand \& Vølstad 1997). Imports to other oyster farms in Norway followed until 1986, when import regulations became stricter (Strand \& Vølstad 1997). Determining exactly when cultivation in Norway ceased is difficult, as farmers stopped importing and cultivating Pacific oysters some years before the last cultivation licence was retracted in 2010 (Bodvin et al. 2014). In Sweden, cultivation trials of the Pacific oyster were performed between 1973 and 1976 on the northern west coast (Eklund et al. 1977), but no commercial activities associated with the species have taken place. In 2007, many independent observations of Pacific oyster settlement on the west coast of Sweden and Norway were reported, indicating a large recruitment in 2006. Since then, despite both high winter (Strand et al. 2012) and summer mortalities (Mortensen et al. 2016), the species has increased in densities (Strand \& Lindegarth 2014) and is now firmly established in Scandinavian waters (Laugen et al. 2015). Thus, the complex colonization history of the oyster in Scandinavian waters may be used as a good case study to gain further knowledge on processes determining genetic diversity of marine organisms.

Therefore, here we investigated whether the recent establishment of the Pacific oyster in Sweden and southern Norway was sourced artificially from European populations, or naturally by larval dispersal from neighbouring Danish oyster beds. The main production countries from which Pacific oysters are imported are France, the Netherlands and Ireland (Strand \& Lindegarth 2014), which therefore can be considered potential artificial sources. Alternatively, oyster larvae could have been naturally transported by the Jutland current from the Wadden Sea and Limfjord area in Denmark to the Swedish west coast (Wrange et al. 2010), which was proven realistic in oceanographic dispersal modelling (Laugen et al. 2015). It is also important to note that these alternative introduction routes are not mutually exclusive, and that multiple pathways of introduction are possible.

\section{MATERIALS AND METHODS}

\section{Sampling and genetic analysis}

A total of 909 individuals distributed among 19 population samples were collected from 13 different loca- 
tions, including 3 sites with both wild and aquaculture samples, and 3 Swedish sites (Table 1, Fig. 1). Individuals collected at the Swedish sites were separated into 2 classes based on shell length. The 50 largest oysters found at each site (91 to $239 \mathrm{~mm}$ ) were included to represent the major introduction in 2006, whilst the 50 smallest individuals (29 to $81 \mathrm{~mm}$ ) were included to represent local recruitment or repeated introduction as well as temporal replicates (Strand \& Lindegarth 2014). Only the larger size class was collected from the Swedish location Furulund, as no small individuals were present. All samples were collected between 2008 and 2015 (Table 1). Tissue samples were taken from the adductor muscle of each individual and stored in 96\% ethanol (EtOH) until further analysis. Wild oysters from France, the Netherlands, Denmark, Norway and both wild and aquaculture samples from Ireland were collected by local researchers and sent to Sweden as adductor muscle tissue samples stored in $96 \%$ EtOH. Cultivated, diploid oysters from France and the Netherlands were provided by aquaculture companies, which use locally produced spat, and were shipped alive to Sweden where tissue sampling was performed. DNA was extracted from the tissue samples with the NucleoSpin ${ }^{\circledR}$ Tissue Kit (Macherey-Nagel) and E.Z.N.A. ${ }^{\circledR}$ Tissue DNA Kit (Omega Bio-tek) following standard protocols.

Based on reviewed literature, several loci were chosen and tested, after which some were discarded due to amplification failure. In total, 7 microsatellite loci were finally selected for further analysis: $A M Y$ (Sellos et al. 2003), CGE09 (Yu \& Li 2007), Cgsili44 (Sauvage et al. 2009), L10, L48 (Huvet et al. 2000), Cg108 and Cg49 (Magoulas et al. 1998). All loci were amplified using polymerase chain reaction (PCR), and the amplified products were analysed on a CEQ ${ }^{\mathrm{TM}} 8000$ Genetic Analysis System (Beckman Coulter). Raw data were
Table 1. Information about the sampling sites of wild and aquaculture $\left({ }^{*}\right.$ ) Crassostrea gigas. Sample size indicates the number of individuals collected at each site. Swedish size classes are displayed as $1=$ larger individuals (91 to $239 \mathrm{~mm}$ ) and $2=$ smaller individuals $(29$ to $81 \mathrm{~mm})$

\begin{tabular}{|llcccc}
\hline Country & Location & Sample & Sample & Coordinates \\
& & size & year & \\
\hline France & Marennes-Oléron $^{*}$ & 50 & 2015 & $45.8063^{\circ} \mathrm{N}, 1.1788^{\circ} \mathrm{W}$ \\
France & Marennes-Oléron $^{\circ}$ & 50 & 2011 & $45.9113^{\circ} \mathrm{N}, 1.1529^{\circ} \mathrm{W}$ \\
Netherlands & Oosterschelde $^{*}$ & 50 & 2015 & $51.5031^{\circ} \mathrm{N}, 4.0531^{\circ} \mathrm{E}$ \\
Netherlands & Oosterschelde $^{\circ}$ & 49 & 2013 & $51.5031^{\circ} \mathrm{N}, 4.0531^{\circ} \mathrm{E}$ \\
Ireland & Lough Foyle, a & 50 & 2010 & $55.1026^{\circ} \mathrm{N}, 7.2202^{\circ} \mathrm{W}$ \\
Ireland & Lough Foyle & 50 & 2010 & $55.1026^{\circ} \mathrm{N}, 7.2202^{\circ} \mathrm{W}$ \\
Ireland & Lough Swilly & 50 & 2008 & $55.0206^{\circ} \mathrm{N}, 7.5770^{\circ} \mathrm{W}$ \\
Denmark & Wadden Sea & 50 & 2012 & $55.1859^{\circ} \mathrm{N}, 8.6222^{\circ} \mathrm{E}$ \\
Denmark & Limfjorden & 50 & 2012 & $56.7220^{\circ} \mathrm{N}, 8.2578^{\circ} \mathrm{E}$ \\
Sweden 1 & Smalsundet & 50 & 2011 & $58.2488^{\circ} \mathrm{N}, 11.4402^{\circ} \mathrm{E}$ \\
Sweden 1 & Furulund & 50 & 2011 & $58.2753^{\circ} \mathrm{N}, 11.5061^{\circ} \mathrm{E}$ \\
Sweden 1 & Krokesundet & 49 & 2011 & $58.8617^{\circ} \mathrm{N}, 11.1746^{\circ} \mathrm{E}$ \\
Sweden 1 & Svallhagen & 50 & 2011 & $58.8684^{\circ} \mathrm{N}, 11.1551^{\circ} \mathrm{E}$ \\
Sweden 2 & Smalsundet & 50 & 2011 & $58.2488^{\circ} \mathrm{N}, 11.4402^{\circ} \mathrm{E}$ \\
Sweden 2 & Krokesundet & 50 & 2011 & $58.8617^{\circ} \mathrm{N}, 11.1746^{\circ} \mathrm{E}$ \\
Sweden 2 & Svallhagen & 50 & 2011 & $58.8684^{\circ} \mathrm{N}, 11.1551^{\circ} \mathrm{E}$ \\
Norway & Tromlingene & 46 & 2013 & $58.4748^{\circ} \mathrm{N}, 8.9067^{\circ} \mathrm{E}$ \\
Norway & Hui & 46 & 2012 & $59.1258^{\circ} \mathrm{N}, 10.3651^{\circ} \mathrm{E}$ \\
Norway & Espevik & 19 & 2010 & $59.3019^{\circ} \mathrm{N}, 5.6988^{\circ} \mathrm{E}$ \\
& & & &
\end{tabular}

${ }^{a}$ For labelling purposes, Lough Foyle was referred to as 'Ireland', however, we recognise that Lough Foyle is currently regulated by a cross-border body (Republic of Ireland/Northern Ireland)

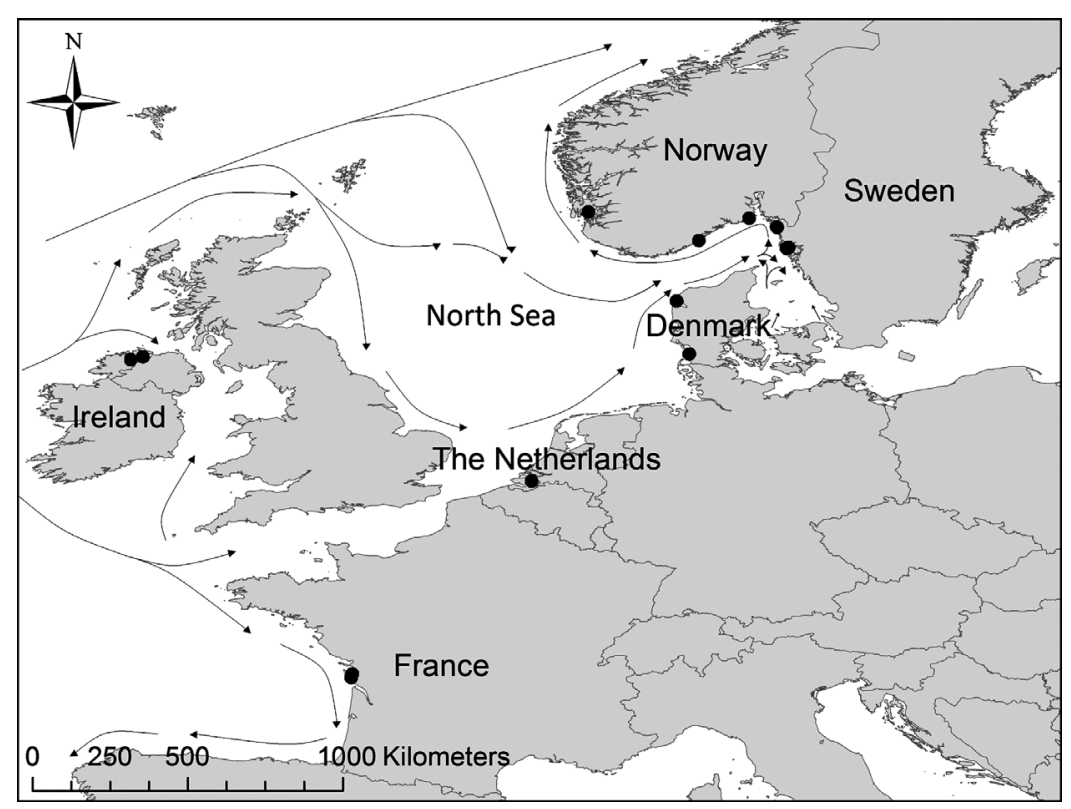

Fig. 1. Sampling locations (๑) of wild and aquaculture Crassostrea gigas individuals across northern Europe including main ocean currents (indicated by arrows) 
analysed and genotyped with the CEQ Fragment Analysis software. Individuals that could not be genotyped confidently were re-amplified and re-analysed 3 times before being given null values.

\section{Statistical analysis}

In each population sample, observed and expected heterozygosity $\left(H_{0}, H_{\mathrm{e}}\right)$ were assessed in GenAlEx 6.501 (Peakall \& Smouse 2006, 2012), and number of alleles $\left(N_{\mathrm{a}}\right)$ and allelic richness $\left(A_{\mathrm{R}}\right)$ were calculated in FSTAT (Goudet 2002) for each locus. Deviations from Hardy-Weinberg (HW) proportions were analysed by estimating $F_{\text {IS }}$ according to Weir \& Cockerham (1984) and calculated in Genepop v.4.3 (Rousset 2008). Moreover, HW exact probability tests were performed in Genepop, using the Markov chain algorithm with the following parameters: 10000 dememorization steps, 1000 batches and 5000 iterations batch $^{-1}$. Significance was assessed using false discovery rate (FDR) corrected p-values (q) to account for multiple testing (Benjamini \& Hochberg 1995). The software MICRO-CHECKER v.2.2.3 (20 000 bootstraps) was used to identify possible null alleles and genotyping errors due to stuttering and large allele drop-out (van Oosterhout et al. 2004). Evolutionary neutrality of the markers was tested in LOSITAN (50 000 simulations; FDR: 0.05), which simulates the distribution of $F_{\mathrm{ST}}$ versus heterozygosity to estimate the $F_{\mathrm{ST}}$ distribution under the null hypothesis of no selection (Antao et al. 2008).

Pairwise $F_{\text {ST }}(\theta)$ were calculated according to Weir \& Cockerham (1984) in GENETIX v.4.05 (Belkhir et al. 1996-2004) to estimate genetic differentiation between samples. Significance of $F_{\mathrm{ST}}$ values was tested using 9999 permutations, and was corrected for multiple testing using FDR. To investigate if any locus had a disproportionate contribution to the joint $F_{\mathrm{ST}}$ estimates, a jack-knife resampling over loci was applied by systematically omitting one locus at a time. A classical (metric) multidimensional scaling analysis (MDS) was performed on pairwise $F_{\mathrm{ST}}$ values using the $\mathrm{R}$ function 'cmdscale' (R Core Team $2014)$ to visualise any possible population structure. Population pairwise estimates of Jost's $D$ (Jost 2008) in GenAlEx v.6.501 were used to ensure that high heterozygosity levels did not bias $F_{\mathrm{ST}}$ estimates.

The individual-based clustering method STRUCTURE v.2.3.4 (Pritchard et al. 2000) was used to estimate the most likely number of population clusters $(K)$ among the sampled locations. The burn-in period was set to 10000 and the number of Markov chain
Monte Carlo (MCMC) repetitions to 50 000. Clusters $K$ from 1 to 19 were run 20 times $K^{-1}$. No admixture was used, as each individual was assumed to originate from one of the populations sampled, and Locprior was set to be able to detect lower levels of divergence with the assistance of the sample group information (Hubisz et al. 2009). The different runs were merged for visual analysis with CLUMPAK (Kopelman et al. 2015), and the most likely number of $K$ was estimated using STRUCTURE HARVESTER (Earl \& vonHoldt 2012) by calculating the posterior probability of data for each value of $K$ (mean $\ln P[K]$ ) and the modal value of delta $K$.

Analysis of molecular variance (AMOVA) was performed in Arlequin v.3.5.2.2 (Excoffier \& Lischer 2010). Molecular variance was divided into 3 hierarchicallevels: among clusters as identified by STRUCTURE, among samples within clusters and within samples. Significance was assessed using 10100 permutations. Gene flow among populations was estimated by calculating the directional relative migration using the webbased software application divMigrate-online (Sundqvist et al. 2016) based on the GST statistic (Nei 1973).

Genetic assignment and exclusion tests were performed in GeneClass2 (Piry et al. 2004) to estimate the probability of each individual belonging to any of the potential source samples included in the analysis. The exclusion test was performed using Monte Carlo resampling according to Paetkau et al. (2004), to estimate the probability of each individual originating from a population not sampled. In total, 10000 individuals were simulated, and individuals that had $<5 \%$ probability of originating from any of the sampled locations were excluded from all assignments. Source samples in close geographical proximity that showed no significant differentiation and belonged to the same size class (French wild and aquaculture, Danish Limfjorden and Wadden Sea, as well as Swedish samples of the same size class), were then pooled together to allow for clearer assignments. The likely origin of oysters was evaluated in 2 separate assignment analyses. First, all collected individuals were assigned to any of the population samples using a self-assignment test, where the assigned individual was excluded as a reference in the sample from which it was taken (leave-one-out procedure; Efron 1983). Second, to estimate the most likely origin of the Swedish and Norwegian oysters, all individuals collected in Sweden and Norway were assigned to the French, Dutch, Irish or Danish population samples. Both tests were performed according to the procedure described by Rannala \& Mountain (1997). Individuals were considered successfully assigned 
only if assignment with the highest score was twice as likely as the assignment with the second highest score $\left(\operatorname{rank} 1 \times \operatorname{rank} 2^{-1}>2\right)$, ensuring robustness in the assignment result.

\section{RESULTS}

A total of 902 of the 909 collected oysters were successfully genotyped at 4 or more loci. Genotyping success was above $98 \%$ for all loci except for Cgsili44, which had a genotyping success of $88 \%$. The sample displaying the lowest genotyping success was the Dutch wild sample, which had an average of $84 \%$ successfully genotyped individuals, while all other samples averaged above 90\%. MICRO-CHECKER found no evidence of null alleles or genotyping errors, and LOSITAN showed no indication of selection acting on any of the loci.

\section{Genetic diversity and HW proportions}

The largest genetic diversity was observed in the French samples and the Dutch wild sample, with an average $N_{\mathrm{a}}$ of 30 to 32 alleles and average $A_{R}$ of 14 to 19. Remaining samples displayed a mean $N_{\mathrm{a}}$ of 11 to 23 and $A_{\mathrm{R}}$ of 11 to 16 . The lowest $N_{\mathrm{a}}$ and $A_{\mathrm{R}}$ values were observed in the smallest sample, Norwegian Espevik, and the wild and aquaculture samples from Irish Lough Foyle. $H_{\mathrm{o}}$ and $H_{\mathrm{e}}$ were high at all locations, ranging from 0.71 to 1 and 0.80 to 0.98 , respectively. A summary of the genetic diversity is presented in Table S1 in the Supplement at www.int-res.com/ articles/suppl/m575p095_supp.pdf.

HW exact tests revealed that locus Cg49 deviated significantly ( $p<0.05$ ) from expected HW proportions for all samples, and was therefore excluded from further analysis. Among the remaining loci, an additional 10 deviations were identified $(q<0.05$; Table S2). More than half of the deviations were found in the aquaculture samples (6 out of 10). Another 3 deviations were found for wild samples in close proximity to aquaculture facilities.

\section{Population structure}

All loci displayed similar differentiation patterns and contributed equally to the pairwise $F_{\text {ST }}$ estimates as shown in the jack-knife resampling (Fig. S1), illustrating the robustness of the $F_{\mathrm{ST}}$ estimates. All loci (except for the previously excluded Cg49) were therefore included in the subsequent analyses. Of the 172 pairwise $F_{\mathrm{ST}}$ tests for genetic differentiation, 124 displayed significant differentiation ( $\mathrm{q}<0.05$; Table S3). Two groups of closely related samples could be identified: a northern group (all samples from Denmark and Sweden as well as the Norwegian Tromlingene sample) and a southern group (French wild, French aquaculture and Dutch wild samples) (Fig. 2b, Table S3). The southern group showed no within-group differentiation $(q<0.05)$ with pairwise $F_{\mathrm{ST}}$ values ranging from -0.0016 to 0.0027 . The a

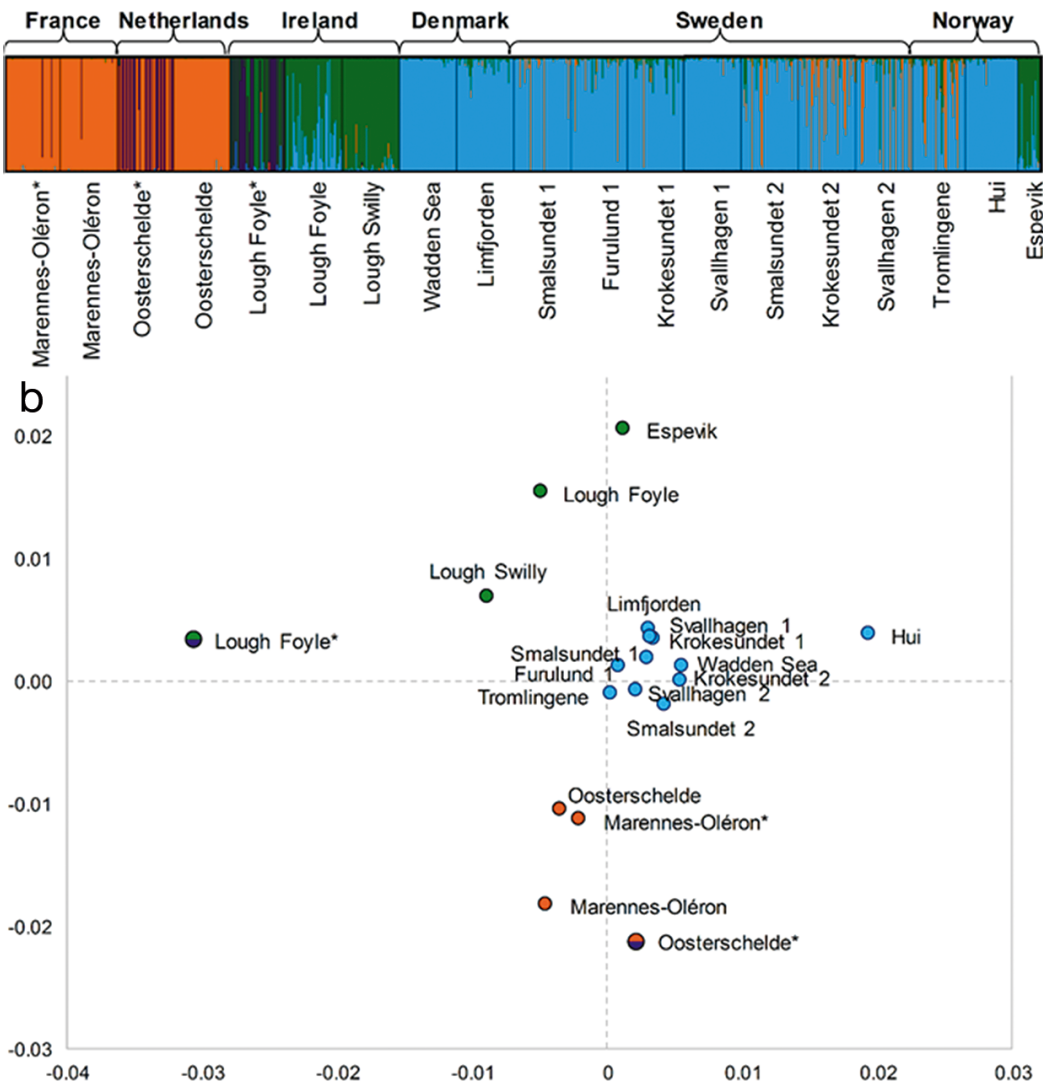

Fig. 2. Genetic population structure of Crassostrea gigas based on 6 microsatellite markers. (a) Output from CLUMPAK, visualising major modes for $K=4$ from the individual-based clustering performed in STRUCTURE. Every vertical line represents 1 individual and the colour shows the proportion of each individual assigned to each of the 4 genetic clusters. (b) Classical metric multidimensional scaling (MDS) analysis, performed on pairwise $F_{\mathrm{ST}}$ estimates. Symbols are colour-coded according to clusters identified in the STRUCTURE analysis. Swedish size classes are displayed as $1=$ larger individuals (91 to $239 \mathrm{~mm}$ ) and $2=$ smaller individuals (29 to $81 \mathrm{~mm}$ ). ${ }^{*}$ Aquaculture samples 
northern group displayed a range of pairwise $F_{\mathrm{ST}}$ estimates of -0.0034 to 0.004 , with the only significant differentiation between the 2 size classes in Swedish Krokesundet $(q=0.031)$. Samples were significantly differentiated between the 2 groups $\left(F_{\mathrm{ST}}=\right.$ 0.0079 to 0.0216 ). All remaining samples, which were not included in the 2 groups (i.e. Hui, Espevik, Ireland, and Dutch aquaculture) were significantly differentiated in all pairwise tests. Patterns of pairwise Jost's $D$ showed identical results (data not shown).

A closer inspection of pairwise $F_{\mathrm{ST}}$ estimates and the MDS analysis revealed additional patterns of population structure (Fig. 2b, Table S3). A third putative western group could be observed from the MDS, where Irish wild samples (Lough Foyle and Lough Swilly) and the Norwegian Espevik sample appeared separated from the other 2 groups. The western group was less divergent from the northern group $\left(F_{\mathrm{ST}}=0.0065\right.$ to 0.0257$)$ than from the southern one $\left(F_{\mathrm{ST}}=0.0199\right.$ to 0.0415$)$. Moreover, Norwegian Hui was more related to the northern group $\left(F_{\mathrm{ST}}=0.0053\right.$ to 0.0124$)$, and the Dutch aquaculture sample was closer to the southern group. Finally, the Lough Foyle Farm sample was strongly differentiated from all other samples.

The STRUCTURE clustering analysis was used to identify groups based only on genetic similarities among individuals. The mean $\ln P(K)$ plateaued at $K=4$ (Fig. S2), representing the most likely number of population clusters. Delta $K$ displayed clear peaks at $K=2$ and $K=4$, capturing the major structure of the data set (Fig. S3). These results suggested the existence of 4 genetically differentiated clusters (Fig. 2a). The first 2 clusters corresponded closely to the southern and northern groups (orange and blue, respectively), in concordance with pairwise $F_{\mathrm{ST}}$ estimates and assignment tests (below). Moreover, Norwegian Hui clustered with the northern group. The third cluster (green) grouped the wild Irish samples with the Norwegian Espevik sample, in accordance with the low divergence found with pairwise $F_{\mathrm{ST}}$ tests. In addition, the wild Lough Foyle sample also displayed a large proportion of individuals partly admixed with the northern group (blue). Both Lough Foyle aquaculture and Dutch aquaculture samples appeared to consist of mixed populations, with connections to both the green and orange clusters as well as a fourth cluster (purple).

The AMOVA performed on the clusters identified by STRUCTURE (blue: all Danish, Swedish and Norwegian Tromlingene and Hui; orange: all French and wild Dutch; green: wild Irish and Norwegian Espevik; purple/green: Irish aquaculture; purple/orange:
Dutch aquaculture) showed that the genetic differentiation among clusters $\left(F_{\mathrm{CT}}=0.0167, \mathrm{p}<0.0001\right)$, was more than 5 times those among samples within clusters $\left(F_{\mathrm{SC}}=0.00323, \mathrm{p}<0.0001\right)$. Similar results were obtained when excluding aquaculture samples $\left(F_{\mathrm{CT}}=\right.$ $\left.0.0131, F_{\mathrm{SC}}=0.00344\right)$.

\section{Migration patterns and assignment tests}

The analysis of directional migration dynamics revealed a network (Fig. 3a) where populations grouped in a similar way to what was observed in the MDS based on pairwise $F_{\mathrm{ST}}$ values. The main difference being that Espevik did not cluster with the wild Irish samples. Instead, cultured and wild Irish samples formed a putative group. The network demonstrated strong directional relative migration (above 0.5) within the southern group and the northern group (Fig. 3b), respectively.

Finally, the probability of each individual originating from any of the populations included in the study was explored with exclusion and assignment tests. In the individual-based exclusion test, all but 5 individuals had $>5 \%$ probability of originating from at least 1 of the 19 samples. The 5 individuals that had lower probability were excluded from all assignment tests. When tested for robust assignments (rank1 $\times$ rank $2^{-1}$ $>2$ ), 341 of 897 individuals were excluded from the self-assignment test and 95 of 459 of Swedish and Norwegian individuals from the assignment to population of putative origin. To control for exclusion effects, all assignments were also performed using all individuals, which resulted in only minor changes in proportions, thus confirming the robustness of the results. The assignment results are displayed as percentages in heat maps (Fig. 4). The self-assignment showed similar patterns as the $F_{\mathrm{ST}}$. In the northern group (Denmark, Sweden and Norwegian Tromlingene) $65 \%$ of the individuals were assigned within the northern group, and in the southern group (French and wild Dutch samples) $78 \%$ of the individuals were assigned within the group, of which the majority was assigned to France. Samples that showed differentiation to all other samples in the pairwise $F_{\mathrm{ST}}$ demonstrated the highest assignment to their own source: the highest proportion of selfassignment was found for Dutch aquaculture $(68 \%)$ and Irish aquaculture $(66 \%)$. In accordance with $F_{\mathrm{ST}}$ estimates and individual clustering, a large proportion of individuals from Norwegian Hui, Irish Lough Foyle and Lough Swilly assigned to the northern group (40,27 and $24 \%$, respectively). 


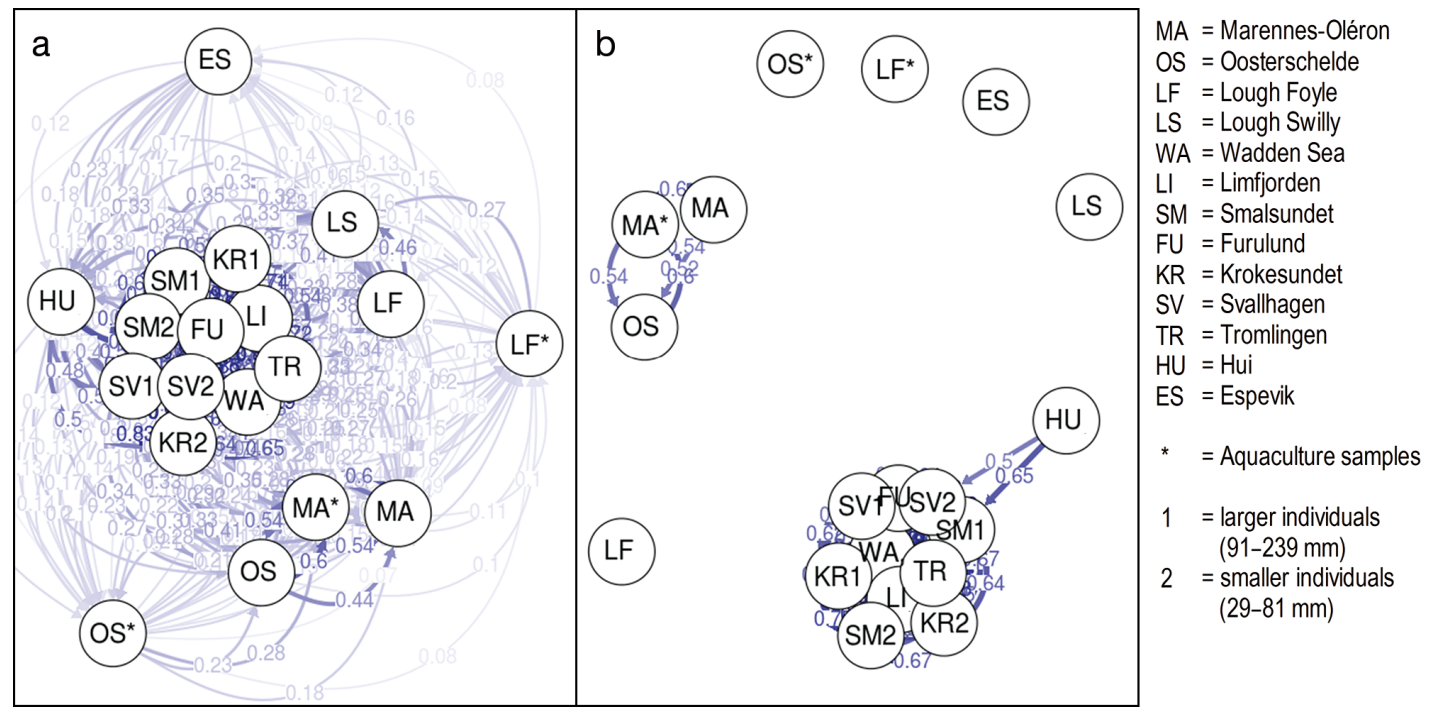

Fig. 3. Directional relative migration of Crassostrea gigas calculated by divMigrate-online using $G_{\mathrm{ST}}$. Arrows indicate the direction of gene flow, and numbers show relative migration coefficient. Arrows with higher numbers appear thicker and stronger in colour. (a) Network based on migration values; (b) network based on values above 0.5 only
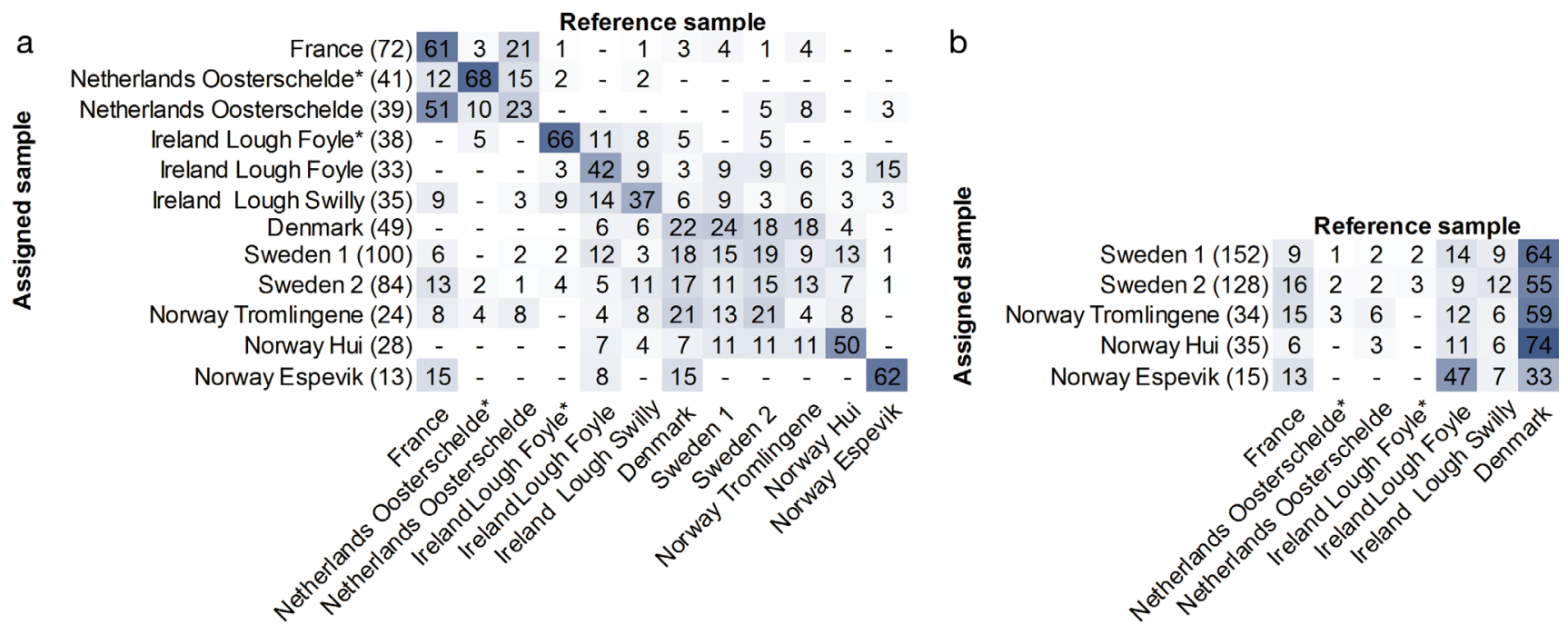

Fig. 4. Heat map of individual assignment of Crassostrea gigas. Samples in close geographical proximity that showed no significant differentiation are pooled: France (aquaculture and wild samples), Sweden 1 (all Swedish samples of larger individuals, 91 to $239 \mathrm{~mm}$ ), Sweden 2 (all Swedish samples of smaller individuals, 29 to $81 \mathrm{~mm}$ ), Denmark (Limfjorden and Wadden Sea). Values displayed in brackets are number of individuals assigned and remaining values are percentage of individuals assigned. (a) Self-assignment where numbers display percentage of individuals assigned to samples based on likelihood. (b) Assignment to population of potential origin. Percentage of individuals from Sweden and Norway assigned to populations of potential origin. *Aquaculture samples

To estimate the origin of introduction, oysters collected in Norway and Sweden were assigned to populations of potential origin. The majority of individuals collected in Sweden assigned to Denmark (Fig. 4b). Remaining individuals from Sweden were mainly assigned to French and wild Irish samples.
Very few individuals collected in Sweden were assigned to the Dutch or Irish aquaculture. Norwegian Tromlingene and Hui demonstrated a similar pattern, with 59 and $74 \%$ assignment to Denmark, respectively. Norwegian Espevik did, however, assign mainly to the wild Irish Lough Foyle sample. 


\section{DISCUSSION}

Our results do not support the assumption that France, the Netherlands or Ireland are the main sources of the Swedish and Norwegian populations of Pacific oysters. Rather, the lack of genetic differentiation between oysters from Denmark and Sweden indicates that Danish oysters are the likely source of origin of the Swedish populations, or that Danish and Swedish oysters share common ancestry. The analysis of origin of the Norwegian oysters shows a more mixed pattern. The majority of oysters in Tromlingene likely originate or receive significant gene flow from Swedish and/or Danish populations. Although Hui was closely related to Swedish and Danish oysters, and Espevik to Irish oysters, we were not able to conclusively determine the origin of these 2 populations.

\section{Genetic diversity patterns}

Several populations showed deviations from HW proportions in the form of heterozygote deficiency, consistent with previous studies of the Pacific oyster (Meistertzheim et al. 2013, Rohfritsch et al. 2013, Lallias et al. 2015). However, only weak general patterns in heterozygote deficiency across samples or populations were observed: the Irish aquaculture sample showed a pattern of consistent deficit across loci indicative of inbreeding or a Wahlund effect (when a sampled 'population' is a mixture of different subpopulations; Wahlund 1928). Although heterozygote deficiency was observed in some of the samples, both $H_{\mathrm{o}}$ and $H_{\mathrm{e}}$ were relatively high for all samples across all loci, in agreement with previous studies performed on Crassostrea gigas (Li et al. 2006, Kochmann et al. 2012, Rohfritsch et al. 2013, Lallias et al. 2015). On the other hand, when considering $N_{\mathrm{a}}$ and $A_{\mathrm{R}}$, higher genetic diversity was observed in the southern group. Likely explanations include repeated introduction of spat for aquaculture and/or genetic loss in the northern locations as a result of bottlenecks during range expansion from the older southern groups, and subsequent inbreeding and genetic drift. Bottlenecks were previously observed in the northern expansion of the Pacific oyster in Europe, although only minor loss in genetic variability was detected (Meistertzheim et al. 2013). Bottlenecks are known to have relatively little effect on heterozygosity but may reduce the number of alleles very quickly (Allendorf 1986). This would explain why samples displayed large variation in allelic diversity $\left(N_{\mathrm{a}}\right.$ and $\left.A_{\mathrm{R}}\right)$, but showed little to no difference in heterozygosity $\left(H_{\mathrm{o}}\right.$ and $\left.H_{\mathrm{e}}\right)$.

\section{Origin of the Pacific oyster in Sweden}

Across all analyses, we detected significant genetic differentiation between the Swedish samples and those collected in countries producing oysters (France, the Netherlands and Ireland). Therefore, the presence of Pacific oysters in Sweden is unlikely to be a result of re-laying and subsequent spawning of cultured oysters imported for consumption in Sweden. Moreover, no genetic differentiation was found between Swedish and Danish samples, which indicates connectivity between Denmark and Sweden, or a common recent origin.

Oceanographic current trajectory modelling by Laugen et al. (2015) demonstrates that, although unlikely for larvae from the Danish Wadden Sea, larvae from the Danish Limfjord can be transported with the Jutland current to the Swedish west coast. The dispersal model also indicates that if larvae were transported to Sweden with the Jutland current, the majority would end up in the area around Gothenburg and northwards, which is in accordance with observations from 2007 (Wrange et al. 2010). Although no genetic differentiation was found among Danish and Swedish samples, samples from Sweden exhibited higher allelic richness than samples from the Danish Wadden Sea, and similar or slightly higher average allelic richness than samples from the Limfjord. This could be a result of Swedish oysters having multiple source populations, as some individuals (especially juveniles) appear to originate from France/the Netherlands/Ireland (Fig. 2a).

In contrast to the observed genetic similarities between oysters in the Danish Wadden Sea and the Limfjord in the present study, the oceanographic particle transport study by Laugen et al. (2015) and data presented by Rohfritsch et al. (2013) suggest that the Danish Wadden Sea and the Limfjord may not be well connected. We observed higher genetic diversity (allelic richness) in the Limfjord compared to the Danish Wadden Sea, which suggests that Pacific oysters in Denmark may have multiple sources of origin and/or that each population may have slightly evolved in response to genetic drift associated with demographic processes creating chaotic genetic patchiness (David et al. 1997, Broquet et al. 2013). Variability in recruitment success may lead to genetic variability at a small spatio-temporal scale (Hedgecock \& Pudovkin 2011). This phenomenon has been well demonstrated in marine invertebrates (Riquet et al. 2016) and may very well explain the different levels in genetic diversity between the 2 Danish samples, as well as the contrasted results with Rohfritsch et al. (2013). 


\section{Origin of the Pacific oyster in Norway}

The origin of Pacific oysters in Norway seems to be more complex than that of the oysters in Sweden. All 3 Norwegian samples were genetically distinct and showed a varying degree of genetic differentiation in relation to other samples. This suggests that Pacific oysters in Norway may originate from multiple sources. The sample from Tromlingene was not differentiated from either Danish or Swedish samples, suggesting connectivity between Tromlingene and either Sweden and/or Denmark. The dispersal model by Laugen et al. (2015) demonstrates that it is indeed possible for oyster larvae from Sweden to spread north-east along the Norwegian coast, which could explain the connectivity between Swedish and Norwegian oysters.

Although geographically closer to Sweden, Norwegian Hui did not demonstrate the same level of genetic similarity to the Swedish and Danish samples as Tromlingene. Whilst pairwise $F_{\mathrm{ST}}$ values suggested a dissimilarity from the northern group, the relatively low $F_{\mathrm{ST}}$ values, STRUCTURE results, assignments and directional relative migration $(0.23$ to 0.65) suggest a close connection between Hui and the northern group. Possible causes of this seemingly contradictory pattern could be that Pacific oysters in Hui originate (1) from an unsampled population closely related to the northern group; (2) from a mixture of multiple sources, one of which is the northern group; or (3) from the northern group, but represent a more extreme founder event. The last case is the most probable, as Hui has relatively low allelic diversity and appears to be the least admixed northern population (Fig. 2a).

The Norwegian Espevik has a history of importing and exporting Pacific oyster spat from the British Isles (Strand \& Vølstad 1997). This historical background is likely to explain the genetic differentiation pattern observed in the MDS and clustering analyses, which grouped Espevik and the wild Irish samples. Nonetheless, pairwise $F_{\mathrm{ST}}$ revealed some genetic heterogeneity between oysters from Espevik and Ireland, suggesting that Espevik oysters appear, at least in part, to originate from or share history with Irish oysters.

\section{CONCLUSIONS}

The results presented in this study point to a high interconnectivity among Scandinavian oyster populations, which was previously suspected but not established. We conclude that the invasive Pacific oyster, which is now well established in Sweden, likely originated from Danish populations, and that larval drift is the most probable pathway of introduction. This means that even if the Pacific oyster was to become locally extinct in Sweden and Norway, by natural or anthropogenic causes, re-colonization from Danish populations can be expected. Also, established populations in Norwegian Tromlingene, and to some extent Hui, are likely to be a result of larval drift from Sweden and/or Denmark. Overall, genetic diversity patterns in this study are consistent with oceanographic drift models (Laugen et al. 2015), showing that such transport is probable, and may occur repeatedly. This insight highlights the importance of trans-national collaboration and a joint development of management plans; for example, a country-specific management program aimed at the eradication of the Pacific oyster, such as suggested by Guy \& Roberts (2010), would be futile. Yet, transnational management is hard to achieve due to country-specific variations in interpretations of international legislation, national agendas and legislation, and societal perceptions of the species as a menace or a resource. With the genome of the Pacific oyster now sequenced (Zhang et al. 2012), it would be possible to investigate the observed connectivity further at a genome-wide level. Moreover, possible adaptations to a colder environment and the potential for future range expansion as suggested by Sussarellu et al. (2015) should be assessed to further assist informed management decisions.

The recent increase in mean temperature of Scandinavian waters is likely to continue (IPCC 2014), making future invasions of warm-water species probable. Knowing the pathway of introduction for the Pacific oyster may therefore inform our predictions about other organisms with similar life histories, which in turn provides insights about future invasions of other alien species. Thus, establishing pathways of introduction and current distributions of species that may impact native ecosystems will assist in determining (1) whether management actions are needed, (2) the geographic extent of possible management actions, and (3) the efficiency of those management actions.

Acknowledgements. We express our deep thanks to Torjan Bodvin, Stein Mortensen, Sylvie Lapègue, Herrman Hummel, Stefano Mariani and Jennifer Coughlan for their valuable assistance with sample collection; to Eva-Lotta Blom, Karin André and Melike Kazak for assistance with tissue preparation and DNA extractions; to Anna-Karin Ring for 
lab work; and to Anders Hall for information on shipping routes and ballast water. Comments from the editor and 3 reviewers helped improve the manuscript. FORMAS (grant 2011-1132), the Linnaeus grant (www.cemeb.science.gu.se), EU Interreg (MarGen), and the private foundations Olle Engkvist byggmästare, Herbert \& Karin Jacobssons stiftelse, Stiftelsen Birgit och Birger Wåhlströms minnesfond för den Bohuslänska havs- och insjömiljön, Helge Ax:son Johnsons stiftelse and Lundgrenska stiftelserna supported this study financially through grants to Å.S.

\section{LITERATURE CITED}

Allendorf FW (1986) Genetic drift and the loss of alleles versus heterozygosity. Zoo Biol 5:181-190

* Antao T, Lopes A, Lopes RJ, Beja-Pereira A, Luikart G (2008) LOSITAN: a workbench to detect molecular adaptation based on a $F_{s t}$-outlier method. BMC Bioinformatics 9:323

Balloux F, Lugon-Moulin N (2002) The estimation of population differentiation with microsatellite markers. Mol Ecol 11:155-165

Belkhir K, Borsa P, Chikhi L, Raufaste N, Bonhomme F (1996-2004) GENETIX 4.05, logiciel sous Windows ${ }^{\mathrm{TM}}$ pour la génétique des populations. Laboratoire Génome, Populations, Interactions, CNRS UMR 5000, Universite de Montpellier II, Montpellier

Benjamini Y, Hochberg Y (1995) Controlling the false discovery rate: a practical and powerful approach to multiple testing. J R Stat Soc B 57:289-300

Bodvin T, Rinde E, Mortensen S (2014) Faggrunnlag stillehavsøsters (Crassostrea gigas). Institute of Marine Research, Bergen

Broquet T, Viard F, Yearsley JM (2013) Genetic drift and collective dispersal can result in chaotic genetic patchiness. Evolution 67:1660-1675

Costello MJ, Coll M, Danovaro R, Halpin P, Ojaveer $\mathrm{H}$, Miloslavich P (2010) A census of marine biodiversity knowledge, resources, and future challenges. PLOS ONE 5:e12110

* Crooks JA (2002) Characterizing ecosystem-level consequences of biological invasions: the role of ecosystem engineers. Oikos 97:153-166

David P, Perdieu MA, Pernot AF, Jarne P (1997) Finegrained spatial and temporal population genetic structure in the marine bivalve Spisula ovalis. Evolution 51: 1318-1322

Dlugosch KM, Parker IM (2008) Founding events in species invasions: genetic variation, adaptive evolution, and the role of multiple introductions. Mol Ecol 17:431-449

* Drinkwaard AC (1998) Introductions and developments of oysters in the North Sea area: a review. Helgol Meeresunters 52:301-308

* Earl DA, vonHoldt BM (2012) STRUCTURE HARVESTER: a website and program for visualizing STRUCTURE output and implementing the Evanno method. Conserv Genet Resour 4:359-361

Efron B (1983) Estimating the error rate of a prediction rule: improvement on cross-validation. J Am Stat Assoc 78: 316-331

Eklund U, Håkansson M, Haamer J (1977) En undersökning om förutsättningarna för ostron odling vid svenska västkusten. Chalmers Tekniska Högskola och Göteborgs Universitet Publ B 83, Göteborg
Excoffier L, Lischer HEL (2010) Arlequin suite ver 3.5: a new series of programs to perform population genetics analyses under Linux and Windows. Mol Ecol Resour 10: 564-567

Geller JB, Darling JA, Carlton JT (2010) Genetic perspectives on marine biological invasions. Annu Rev Mar Sci 2: 367-393

Goudet J (2002) FSTAT, a program to estimate and test gene diversities and differentiation statistics from codominant genetic markers (version 2.9.3.2.). http://www2.unil.ch/ popgen/softwares/fstat.htm (accessed 26 May 2015)

*Guy C, Roberts D (2010) Can the spread of non-native oysters (Crassostrea gigas) at the early stages of population expansion be managed? Mar Pollut Bull 60:1059-1064

* Hedgecock D, Pudovkin A (2011) Sweepstakes reproductive success in highly fecund marine fish and shellfish: a review and commentary. Bull Mar Sci 87:971-1002

*Hubisz MJ, Falush D, Stephens M, Pritchard JK (2009) Inferring weak population structure with the assistance of sample group information. Mol Ecol Resour 9:1322-1332

*Huvet A, Boudry P, Ohresser M, Delsert C, Bonhomme F (2000) Variable microsatellites in the Pacific Oyster Crassostrea gigas and other cupped oyster species. Anim Genet 31:71-72

IPCC (2014) Climate change 2014: synthesis report. Contribution of Working Groups I, II and III to the Fifth Assessment Report of the Intergovernmental Panel on Climate Change. IPCC, Geneva

Jost L (2008) $G_{\mathrm{ST}}$ and its relatives do not measure differentiation. Mol Ecol 17:4015-4026

Kochmann J, Carlsson J, Crowe TP, Mariani S (2012) Genetic evidence for the uncoupling of local aquaculture activities and a population of an invasive species - a case study of Pacific oysters (Crassostrea gigas). J Hered 103:661-671

KKopelman NM, Mayzel J, Jakobsson M, Rosenberg NA, Mayrose I (2015) ClUMPAK: a program for identifying clustering modes and packaging population structure inferences across K. Mol Ecol Resour 15:1179-1191

* Lallias D, Boudry P, Batista FM, Beaumont A, King JW, Turner JR, Lapègue $S$ (2015) Invasion genetics of the Pacific oyster Crassostrea gigas in the British Isles inferred from microsatellite and mitochondrial markers. Biol Invasions 17:2581-2595

Laugen AT, Hollander J, Obst M, Strand ^ (2015) The Pacific oyster (Crassostrea gigas) invasion in Scandinavian coastal waters: impact on local ecosystem services. In: Canning-Clode J (ed) Biological invasions in changing ecosystems: vectors, ecological impacts, management and predictions. De Gruyter Open, Warsaw, p 232-257

$\mathrm{Li} \mathrm{Q}, \mathrm{Yu} \mathrm{H}, \mathrm{Yu} \mathrm{R}$ (2006) Genetic variability assessed by microsatellites in cultured populations of the Pacific oyster (Crassostrea gigas) in China. Aquaculture 259:95-102

Magoulas A, Gjetvaj B, Terzogoul V, Zouros E (1998) Three polymorphic microsatellites in the Japanese oyster, Crassostrea gigas (Thunberg). Anim Genet 29:69-70

*Meistertzheim AL, Arnaud-Haond S, Boudry P, Thébault MT (2013) Genetic structure of wild European populations of the invasive Pacific oyster Crassostrea gigas due to aquaculture practices. Mar Biol 160:453-463

Miossec L, Le Deuff RM, Goulletquer P (2009) Alien species alert: Crassostrea gigas (Pacific oyster). ICES Coop Res Rep 299:1-42

Moehler J, Wegner KM, Reise K, Jacobsen S (2011) Invasion genetics of Pacific oyster Crassostrea gigas shaped by 
aquaculture stocking practices. J Sea Res 66:256-262

Mortensen S, Strand $\AA$, Bodvin T, Alfjorden A and others (2016) Summer mortalities and detection of ostreid herpesvirus microvariant in Pacific oyster Crassostrea gigas in Sweden and Norway. Dis Aquat Org 117:171-176

Nei M (1973) Analysis of gene diversity in subdivided populations. Proc Natl Acad Sci USA 70:3321-3323

Padilla DK (2010) Context-dependent impacts of a nonnative ecosystem engineer, the Pacific oyster Crassostrea gigas. Integr Comp Biol 50:213-225

Paetkau D, Slade R, Burden M, Estoup A (2004) Genetic assignment methods for the direct, real-time estimation of migration rate: a simulation-based exploration of accuracy and power. Mol Ecol 13:55-65

Peakall R, Smouse PE (2006) GENALEX 6: genetic analysis in Excel. Population genetic software for teaching and research. Mol Ecol Notes 6:288-295

Peakall R, Smouse PE (2012) GenALEx 6.5: genetic analysis in Excel. Population genetic software for teaching and research - an update. Bioinformatics 28:2537-2539

Piry S, Alapetite A, Cornuet JM, Paetkau D, Baudouin L, Estoup A (2004) GENECLASS2: a software for genetic assignment and first-generation migrant detection. J Hered 95:536-539

Pritchard JK, Stephens M, Donnelly P (2000) Inference of population structure using multilocus genotype data. Genetics 155:945-959

R Core Team (2014) R: a language and environment for statistical computing. R Foundation for Statistical Computing, Vienna

Rannala B, Mountain JL (1997) Detecting immigration by using multilocus genotypes. Proc Natl Acad Sci USA 94: 9197-9201

Riquet F, Le Cam S, Fonteneau E, Viard F (2016) Moderate genetic drift is driven by extreme recruitment events in the invasive mollusk Crepidula fornicata. Heredity 117 : 42-50

Rohfritsch A, Bierne N, Boudry P, Heurtebise S, Cornette F, Lapègue $S$ (2013) Population genomics shed light on the demographic and adaptive histories of European invasion in the Pacific oyster, Crassostrea gigas. Evol Appl 6: 1064-1078

Rousset F (2008) GENEPOP'007: a complete re-implementation of the GENEPOP software for Windows and Linux. Mol Ecol Resour 8:103-106

Ruesink JL, Lenihan HS, Trimble AC, Heiman KW, Micheli F, Byers JE, Kay MC (2005) Introduction of non-native oysters: ecosystem effects and restoration implications. Annu Rev Ecol Evol Syst 36:643-689

Sauvage C, Boudry P, Lapègue S (2009) Identification and characterization of 18 novel polymorphic microsatellite makers derived from expressed sequence tags in the

Editorial responsibility: Per Palsbøll,

Groningen, The Netherlands
Pacific oyster Crassostrea gigas. Mol Ecol Resour 9: 853-855

K Sellos D, Moal J, Degremont L, Huvet A and others (2003) Structure of amylase genes in populations of pacific cupped oyster (Crassostrea gigas): tissue expression and allelic polymorphism. Mar Biotechnol (NY) 5:360-372

* Sousa R, Gutiérrez JL, Aldridge DC (2009) Non-indigenous invasive bivalves as ecosystem engineers. Biol Invasions 11:2367-2385

Strand $\AA$, Lindegarth S (2014) Japanska ostron i svenska vatten - Främmande art som är här för att stanna. Rapp från Vattenbrukscentrum Väst 2:1-62

* Strand A, Blanda E, Bodvin T, Davids JK and others (2012) Impact of an icy winter on the Pacific oyster (Crassostrea gigas Thunberg, 1793) population in Scandinavia. Aquat Invasions 7:433-440

Strand Ø, Vølstad JH (1997) The Molluscan fisheries and culture of Norway. In: MacKenzie CL Jr, Burrell VG Jr, Rosenfield A, Hobart WL (eds) The history, present condition, and future of the molluscan fisheries of North and Central America and Europe, Vol 3. NOAA Tech Rep NMFS 129, US Department of Commerce, Seattle, WA, p 7-24

Sundqvist L, Keenan K, Zackrisson M, Prodöhl P, Kleinhans D (2016) Directional genetic differentiation and relative migration. Ecol Evol 6:3461-3475

Sussarellu R, Huvet A, Lapègue S, Quillen V and others (2015) Additive transcriptomic variation associated with reproductive traits suggest local adaptation in a recently settled population of the Pacific oyster, Crassostrea gigas. BMC Genomics 16:808

Troost K (2010) Causes and effects of a highly successful marine invasion: case-study of the introduced Pacific oyster Crassostrea gigas in continental NW European estuaries. J Sea Res 64:145-165

*van Oosterhout C, Hutchinson WF, Wills DPM, Shipley P (2004) MICRO-CHECKER: software for identifying and correcting genotyping errors in microsatellite data. Mol Ecol Notes 4:535-538

Wahlund S (1928) Zusammensetzung von populationen und korrelationserscheinungen vom standpunkt der vererbungslehre aus betrachtet. Hereditas 11:65-106

*Weir BS, Cockerham CC (1984) Estimating F-statistics for the analysis of population structure. Evolution 38: 1358-1370

*Wrange AL, Valero J, Harkestad LS, Strand $\varnothing$ and others (2010) Massive settlements of the Pacific oyster, Crassostrea gigas, in Scandinavia. Biol Invasions 12:1145-1152

* Yu H, Li Q (2007) EST-SSR markers from the Pacific oyster, Crassostrea gigas. Mol Ecol Notes 7:860-862

* Zhang G, Fang X, Guo X, Li L and others (2012) The oyster genome reveals stress adaptation and complexity of shell formation. Nature 490:49-54

Submitted: November 15, 2016; Accepted: June 1, 2017 Proofs received from author(s): July 14, 2017 